Ye. V. Kylnytska ${ }^{1}$, orcid.org/0000-0002-0586-820X, S. V. Gluhova ${ }^{2}$, orcid.org/0000-0002-8178-7532, O. M. Kitchenko², orcid.org/0000-0002-3868-5653
1 - Kharkiv National University of Civil Engineering And Architecture, Kharkiv, Ukraine, e-mail: dubrochka@ukr.net 2 - National Technical University "Kharkiv Polytechnic Institute", Kharkiv, Ukraine

\title{
METHODOLOGICAL APPROACH TO THE CREDIT WORTHINESS ESTIMATION OF COUNTERPARTIES AT MINING ENTERPRISES
}

Purpose. Development of a comprehensive methodological approach to the credit worthiness estimation of counterparties in the mining industry as a part of a conservative credit policy.

Methodology. The tasks set in the article have been solved by using modern general scientific and special methods: abstract and logical method - for the implementation of theoretical generalizations, the conclusions and recommendations formation; the hierarchy analysis method - to justify the priority of structural parameters for credit worthiness estimation of counterparties of mining enterprises. Moreover, the authors' own previous research results regarding receivables management are used.

Findings. The structural parameter priority of the credit worthiness estimation of counterparties at mining enterprises within the conservative credit policy has been propose'd, which is substantiated by the hierarchy analysis method. Synthesizing the formed hierarchical model and theoretical achievements on the issues of receivables management, a structural and logical sequence of the credit worthiness estimation of counterparties of mining enterprises has been developed.

Originality. A comprehensive methodological approach to the credit worthiness estimation of counterparties in the mining industry within a conservative credit policy has been developed. Compared to the existing ones, it is a clear algorithm of estimation stages based on a hierarchical model of structural parameters of credit worthiness estimation. The advantages of the authors' development are: system flexibility at the stage of formation of criterion base and structural components; clear formalization of results; detailed structuring of evaluation parameters; the possibility of forming a clear unambiguous conclusion about the credit worthiness estimation of counterparties of mining enterprises; compliance of the methodological tools of the estimation system to current trends in the mining industry.

Practical value. A comprehensive methodological approach to the credit worthiness estimation of counterparties in the mining industry is used to achieve the effective planning, regulation, control, rational organization of relations in the field of cash flow.

Keywords: credit worthiness, evaluation, credit policy, receivables, mining industry

Introduction. The external environment variability, which is particularly acute in the modern world economic society, intensifies and accelerates market fluctuations, which is reflected in all spheres of activity of domestic enterprises. Against the background of these changes, the crisis of mutual defaults is especially acute. By the chain reaction principle, the problems of mass bankruptcy become urgent, which are extremely relevant for the mining industry according to statistics.

The number of business entities in the mining industry features a downtrend (taking into account the lack of statistical data on the occupied territory of the Autonomous Republic of Crimea, the city of Sevastopol and part of the temporarily occupied territories in Donetsk and Luhansk). Thus, it changed from 1.972 enterprises in 2013 to 1.602 enterprises in 2015 and to 1.452 enterprises in 2018. First of all, such a reduction is due to a decrease in the number of business entities in various areas: coal mining - from 286 in 2013 to 103 in 2018; iron production - from 31 in 2013 to 18 in 2018; peat extraction - from 53 in 2013 to 40 in 2018 [1].

Analyzing the data on the volume of output of mining enterprises, we note the positive trend to increase the volume of output from 183.889 billion UAH in 2013, to 201.654 billion UAH in 2015 and in 2018 this value reached 422.368 billion UAH.

It should be emphasized that a steady trend towards growth is due to:

- enterprises specializing in crude petroleum - from 14.420 billion UAH in 2013 to 19.142 billion UAH in 2018;

- enterprises engaged in the extraction of metal ores from 61.913 billion UAH in 2013 to 138.646 billion UAH in 2018;

- economic entities whose profile is to extract other minerals and develop quarries - from 12.696 billion UAH in 2013 to 29.642 billion UAH in 2018 [2].

(C) Kylnytska Ye.V., Gluhova S.V., Kitchenko O. M., 2021
At the same time, we note a significant increase in the costs of mining and quarrying from 147.596 billion UAH in 2013 to 257.018 billion UAH in 2018, namely due to [3]:

- enterprises specializing in oil and natural gas production - from 24.934 billion UAH in 2013 to 73.725 billion UAH in 2018;

- enterprises whose main activity is extraction of metal ores - from 38.656 billion UAH in 2013 to 93.975 billion UAH in 2018;

- enterprises whose profile is to extract other minerals and develop quarries - from 9.717 billion UAH in 2013 to 22.657 billion UAH in 2018.

The costs of bad debt recovery have a significant share in the structure of costs of mining industry $(2.3 \%$ in 2018 and $1.97 \%$ in 2013) [4].

It is also necessary to note a steady growth trend of the part of mining industry debt in the total structure of current costs from $61.06 \%$ in 2013 to $65.46 \%$ in 2018 [4].

However, the increasing of the part of debt at a faster growth rate of sales cannot be interpreted as a negative trend. It may be a natural consequence of economic activity and a form of mutual settlements based on partial prepayment. We should pay attention to such statistics as the structure of debt and its distribution for the comprehensive conclusion. The analysis of these data revealed the following key indicators, such as an increase in the share of overdue debt from $27.3 \%$ in 2013 to $39.67 \%$ in 2018, an increase in the share of bad receivables from $2.97 \%$ in 2013 to $4.36 \%$ in 2018 [4]. That is, there is an increase in the growth rate of "problem" debts and inefficient management, which can lead to a complete loss of control over counterparties' financial arrangements and a critical decline in payment discipline in general.

Based on the above, the issues of improving payment discipline at mining enterprises are becoming urgent.

This issue has been included in the comprehensive credit policy of the enterprise and should be resolved directly as a 
structural stage, such as assessing the solvency of counter parties.

Therefore, it is necessary to pay attention to the methodological basis of this component of the mining industries credit policy because statistic confirms the inefficiency of the existing evaluation system or its complete absence.

Literature review. To improve the credit policy of mining enterprises and assess the credit worthiness of their counterparties as a structural component, it is necessary to pay attention to the existing methodological approaches in the scientific space.

It should be noted that the majority of scientific studies [5, 6] on the credit worthiness estimation are based on foreign methods, which are insufficiently adapted to the conditions and realities of financial and management activities of domestic enterprises.

There are two main directions among the totality of the current material: scientific works, which mainly contain provisions for financial and credit institutions [7-10] and those for business entities [11-13].

The borrower's credit worthiness estimation is substantiated in the scientific work [7]. Moreover, ways of its improvement have been developed as an effective tool of the credit arrangement system between banking institutions and borrowing enterprises without taking into account entrepreneurs.

A significant study on the borrower's credit worthiness estimation has been done in the scientific work [8], but the authors focus exclusively on scoring.

Some authors [9] suggest that the existing problem of the borrower's credit worthiness estimation stems from the banks' attempts to issue unsecured loans and at the same time not to form reserves for credit risk at their own expense. In this case, the potential credit worthiness of any borrower is zero and assumes the presence of $100 \%$ credit risk

The borrower's reliability class has been defined in the work [10] according to the qualitative indicators of their activity for credit decisions by the bank, but in turn the quantitative indicators of credit worthiness assessment are ignored.

Thus, the proposed methods for counterparties' credit worthiness estimation which have been developed for financial institutions [7-10] are not adapted to be used by enterprises due to the complex and time-consuming mathematical and statistical apparatus as well.

Scientific works [11-13], which contain developments directly for enterprises, satisfy all modern industry requirements, but contain a number of controversial issues, as follows:

- lack of clear tools for the credit worthiness estimation of counterparties [11];

- being based only on quantitative indicators of the analysis of a financial condition [12], and by that being deprived of possibility of a complex estimation of qualitative credit worthiness parameters;

- excessive generalization of methodological material [13]. That is the application of a broad approach to credit worthiness estimation of counterparties, which synthesizes such parameters as: experience in a particular industry, business reputation, sales, availability of marketing department, availability of court decisions on recovery cash in favor of other businesses, market capacity, but there is no clear algorithm for assessing credit worthiness and its criteria. The set presented in the paper is too branched and heterogeneous, some parameters of which in themselves are contradictory and difficult to standardize measurement.

Unsolved aspects of the problem. A comparative analysis of the credit worthiness estimation approaches presented in scientific papers [11-13] showed that despite the thoroughness of research and achievements of scientists, each of the approaches has certain contradictions that do not allow using the provisions set out in full and original.

Unresolved is the fundamental issue of low probability of forecasting creditworthiness, which necessitates the forma- tion of a system of its assessment, which would be both comprehensive and appropriate to the specifics of the extractive industry.

The practice of economic activity of mining industry enterprises, which is reflected in the available statistics, also shows the lack of consistent structuring of credit assessment parameters and appropriate methodological tools, which necessitates the development of a comprehensive methodological approach to the credit worthiness estimation of mining industry counterparties within conservatism credit policy.

Purpose is the development of a comprehensive methodological approach of the credit worthiness estimation of mining industry counterparties as a part of a conservative credit policy.

To achieve it, the following tasks were set and solved: the main approaches to credit worthiness estimation were analyzed, the hierarchical model of parameters of credit worthiness estimation of mining industry counterparties within conservative credit policy was developed, a logical-structural scheme of credit worthiness estimation of mining industry was developed.

Methodology. The tasks set in the article were solved by using modern general scientific and special methods: the abstract and logical method - for the implementation of theoretical generalizations, the conclusions and recommendations formation; the hierarchy analysis method - to justify the structural parameters priority for estimation of the counterparties' credit worthiness of mining industries within the conservative credit policy. The authors' own previous research results regarding receivables management are used as well.

Results. The authors propose the application of a conservative type of credit policy for mining enterprises because the object of the study is exclusively the process of the credit worthiness estimation of counterparties in the mining industry as a structural element of credit policy and not independently. The choice of this type is due to the following factors that operate at the present stage of development of the socioeconomic environment:

- enterprises' crisis situation due to reduced solvency;

- immobilization of working capital;

- permanent devaluation of the national currency.

The compliance of the conservative type of credit policy with these factors lies in its basic provisions [14]:

- aimed at minimizing credit risk;

- significant reduction in the number of counterparties with deferred payment due to increased risk;

- minimization of delay of payment terms and its amount; - establishing strict conditions for a loan granting and increasing its cost;

- using of strict receivables collection procedures.

The application of the conservative type of credit policy involves the consistent implementation of two main stages:

1) collection and analysis of information about the counterparties of the mining industry from internal sources;

2) collection and analysis of information about the counterparty from external sources.

These procedures are designed to assess the ability of the mining industry counterparties to fulfill the contract payment terms of products (goods, works, and services) on delay of payment terms.

We emphasize that the evaluation plays a key role in making management decisions regarding the granting of deferred payment and the principles of working with the counterparty as a structural component of credit policy, simple and straightforward execution of the provided stages is considered insufficient aware of these actions importance.

Based on the fact that the estimation is a complex analytical procedure, the result of which is directly transformed into a management decision, it is necessary to establish clear parameters by which to assess the creditworthiness. 
Given that the analytical procedures policy is not identical under the basic provisions of the conservative type of credit policy, there is a hierarchical sequence and all valuation parameters must also be relevant.

Therefore, the main task of this stage of the study is selection of the most informative and effective evaluation parameters. The purpose of research by this method was to develop a system of evaluation and analytical procedures for finding the most priority structural parameters for assessing the credit worthiness of counterparties. The solution of this issue is based on the formation of the criterion base of evaluation as a basis and fundamental limits of indicators and a clear interpretation of the results for the future. Based on the previous conclusions of the study, the definition of basic criteria was carried out using the comprehensive expert method. The poll conducted by online form was attended by 15 respondents: $53.3 \%$ - financial managers and $46.7 \%$ - economists of mining industry. Experts were asked to determine the priority of alternative options for assessing the credit worthiness of counterparties: analysis of the duration of economic arrangements; analysis of payment discipline; analysis of debt repayment terms; analysis of financial condition.

The following criteria are established: complexity; efficiency; certainty. They are based on the experts' survey findings (specialists in receivables management, leading economists of mining industry) and on the properties of the receivables management system of extractive industries.

The hierarchical model of structural parameters of credit worthiness estimation was developed using a formalized apparatus of the method of analysis of hierarchies to substantiate the priority of structural elements of the credit worthiness estimation of counterparties of mining enterprises (Fig. 1)

The priority of structural parameters for developing credit worthiness estimation of counterparties of mining enterprises were set up by using a formalized method of hierarchy analysis. This is an objective basis for developing a complex approach to credit worthiness estimation of counterparties of mining enterprises.

Fig. 1 shows that the analysis of debt repayment conditions occupies the first place among the structural parameters of credit worthiness estimation $(47.6 \%)$.

The analysis of payment discipline $(27.5 \%)$ takes the second place. Analysis of the duration of economic arrangements by the criterion of labor intensity ranks third and it is rated at $17.6 \%$. A small share of the criterion of complexity is the analysis of financial condition (7.3\%). It should be noted that the criteria and the corresponding indicators for each of them are not homogeneous, but important for the formation of credit policy as a whole; however, the hierarchy is inherent in both the indicators within the criterion base and the criteria themselves as a whole.

According to Fig. 1, we can conclude that the reliability of the credit worthiness estimation is the most important criterion, and it is rated at $38.9 \%$ according to experts. The second place is occupied by the criterion of efficiency $(37.24 \%)$. Thus, the criterion of complexity of credit assessment plays a significant role and it is rated $23.86 \%$ according to experts.

According to the criterion of efficiency, the analysis of debt repayment terms $(33.1 \%)$ occupies the largest part among the structural parameters of credit worthiness estimation. The analysis of payment discipline $(29.6 \%)$ takes the second place. Analysis of the duration of economic arrangements by the criterion of efficiency ranks third and it is rated $28.2 \%$. A small share of the criterion of efficiency is the analysis of financial condition (9.3\%).

According to the criterion of reliability, the analysis of the duration of economic relations $(46.5 \%)$ holds the largest share among the structural parameters of credit worthiness estimation. The analysis of payment discipline $(36.5 \%)$ takes the second place. Analysis of the debt repayment terms by the criterion of reliability ranks third and it is rated $9.3 \%$. A small share of the criterion of reliability is the analysis of financial condition $(7.8 \%)$.

The integral values of hierarchy analysis method indicate that the structural parameter "Analysis of the duration of economic arrangements" has a priority and it is rated at $32.8 \%$.

The secondary structural parameter of credit worthiness assessment is the "Analysis of payment discipline" with a minimum share of priority of $31.7 \%$. The "Analysis of debt repayment conditions" is the third structural parameter of creditworthiness estimation with a minimum share of priority of $27.3 \%$. "Analysis of financial condition" is the last structural parameter of creditworthiness estimation with a minimum share of priority of $8.2 \%$.

The structural and logical sequence of creditworthiness estimation of mining industry counterparties has been developed as part of the conservative type of credit policy. It is based on the hierarchical model of structural parameters of creditworthiness estimation of mining industry counterparties and theoretical achievements in the field of receivables management (Fig. 2).

The first stage of creditworthiness estimation is the analysis of the duration of economic arrangements of the counterparty according to the hierarchical model of structural elements (Fig. 1). At this stage the existence of economic relations in retrospect is established according to collection and

Level 1 Establishing the priority of structural parameters for credit worthiness estimation of counterparties of mining enterprises

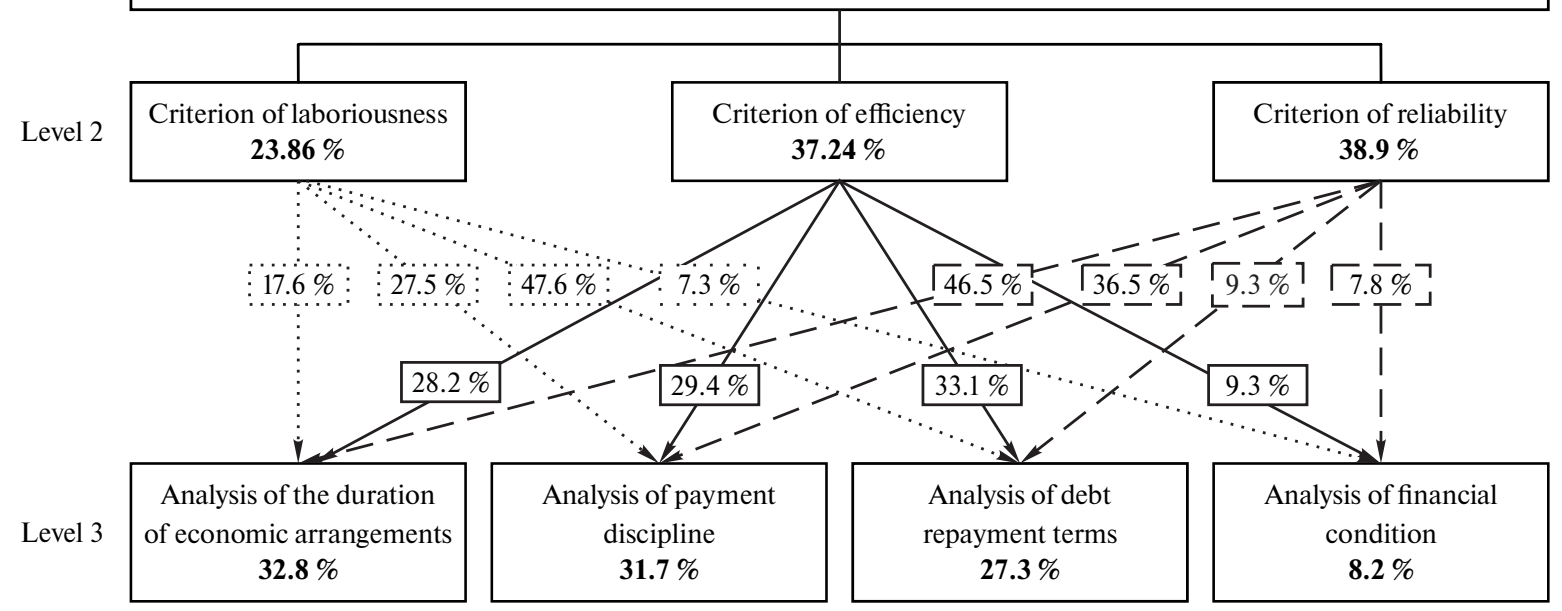

Fig. 1. Hierarchical model of structural parameters for credit worthiness estimation of counterparties of mining enterprises 


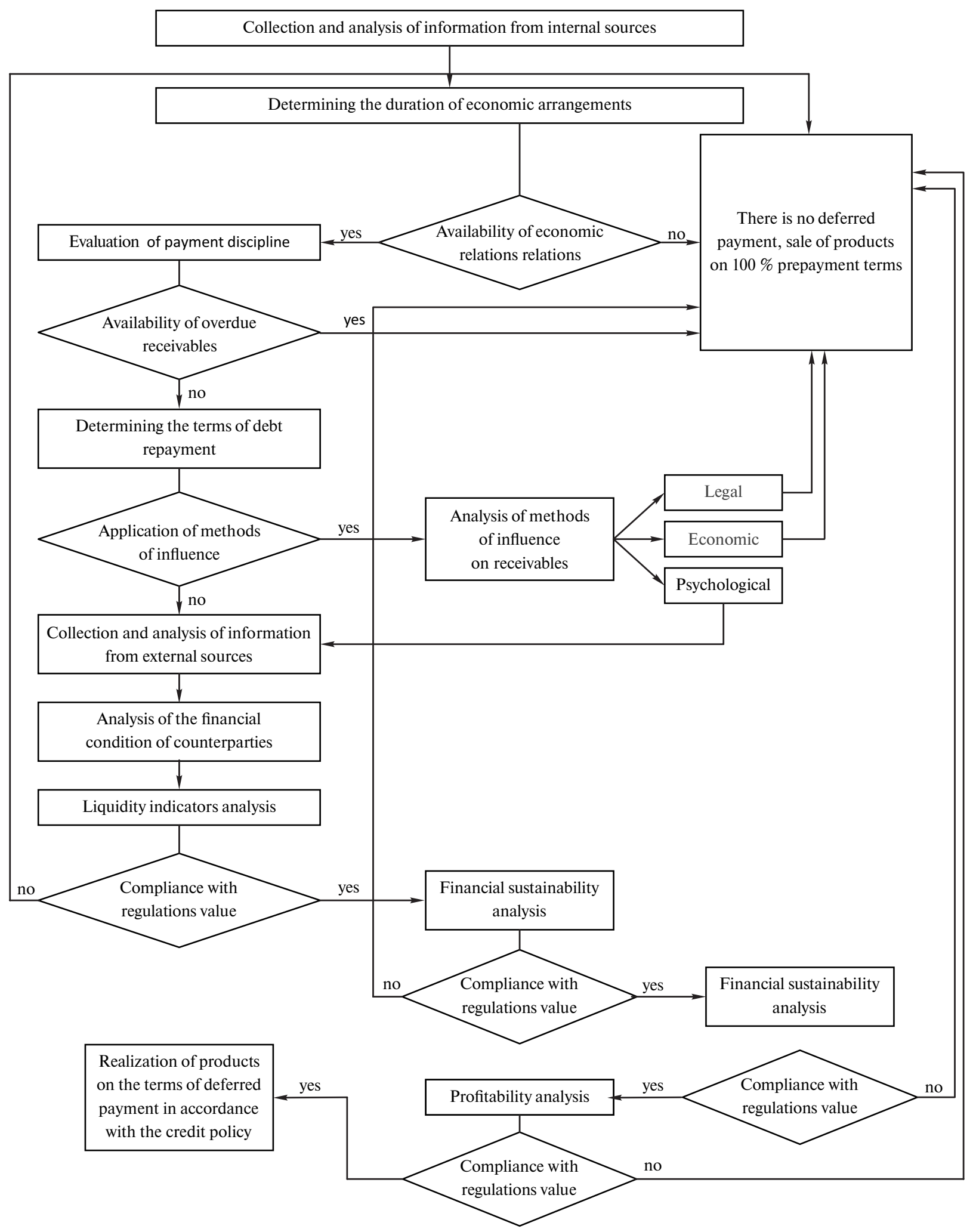

Fig. 2. Structural and logical sequence of the credit worthiness estimation of counterparties in the mining industries

analysis of information from internal sources. If in the previous period the fact of economic arrangement is not confirmed, i.e., there was no previous cooperation with this counterparty, to minimize the risk of overdue receivables or its full repayment, sales are $100 \%$ prepaid and there is no delay in payment.

The sale of products takes place on the terms of $100 \%$ prepayment and there is no delay in payment if in the previous period the fact of economic arrangement is not confirmed, i.e., there was no previous cooperation with this counterparty.
It takes place to minimize the risk of overdue receivables or its full repayment.

If the analysis of the duration of economic arrangement reveals the fact of arrangement, it is advisable to move to the second structural parameter of estimating the counterparty's creditworthiness, which involves the assessment of payment discipline.

If, based on the analysis of information from internal sources, the results of the assessment of payment discipline indicate the fact of overdue debt, regardless of the overdue pe- 
riod and the amount of receivables, sales are $100 \%$ prepaid and there is no delay in payment. Refusal to provide a commodity loan, within the conservative type credit policy, will help eliminate arrears or non-repayment receivables and immobilization of working capital.

The sale of products takes place on the terms of $100 \%$ prepayment and there is no delay in payment if the analysis of information from internal sources shows the assessment results of payment discipline indicate the fact of overdue debt, regardless of the overdue period and the amount of receivables.

If the analysis shows the absence of overdue debt in previous periods of cooperation with the counterparty, it is advisable to move to the third structural parameter of the credit worthiness estimation of counterparties. The third stage involves determining the conditions and methods of influencing the debtors under which the receivables were repaid. The sale of products takes place on $100 \%$ prepayment and there is no delay in payment if the analysis establishes that there is no overdue debt in previous periods of cooperation with the counterparty.

It is advisable to move to the next structural parameter of credit worthiness if the fact of applying methods for influencing the counterparty to collect receivables was absent or the fact of using only psychological methods for influencing (email reminders, phone reminders) receivables in the previous period was established.

Based on the external source's information - financial statements - the analysis of the financial condition is conducted based on the generally accepted areas of analysis: liquidity; financial stability; business activity and profitability. It is advisable to analyze the financial condition of the counterparty in the context of one year quarterly to minimize labor intensity or within two years to observe the dynamics.

As a result of the analysis, compliance with the normative values for each direction is established. In case of non-compliance with the normative values in at least one of the above areas of financial condition analysis, the sale of products takes place on a $100 \%$ prepaid basis and there is no delay in payment.

The sale of products takes place on the delay of payment in accordance with the credit policy of the mining industry if the obtained results of the analysis of the financial condition meet the normative value.

Conclusions. As a result of the research, a comprehensive methodological approach to the credit worthiness estimation of counterparties of mining enterprises within the framework of conservative credit policy has been developed. This approach is based on a hierarchical model of structural parameters of evaluation and involves the implementation of the following stages: analysis of the duration of economic relations; analysis of payment discipline; analysis of debt repayment terms; analysis of financial condition.

A comprehensive methodological approach to the credit worthiness estimation of counterparties in the mining industries allows making an objective and advanced assessment of the ability of counterparties in the mining industries to timely fulfill the contractual terms of products payment (goods, works, services) on the delay of payment terms.

The advantages of the authors' development are: flexibility of the system at the stage of formation of the criterion base and structural components of the indicators; clear formalization of results; detailed and consistent structuring of evaluation parameters; the possibility of forming a clear unambiguous conclusion about the credit worthiness estimation of counterparties in the mining industries both for each of the structural elements and for individual components; compliance of the methodological tools of the evaluation system with the modern features of the mining industry in the conditions of instability of the economic situation.
The results of the study will be the basis for building a mechanism for managing receivables, which will be reflected in further research.

\section{References.}

1. State Statistics Service of Ukraine (n.d.). Number of economic entities by type of economic activity (2013-2018). Retrieved from http:// www.ukrstat.gov.ua.

2. State Statistics Service of Ukraine (n.d.). Volume of output of products (goods, services) of economic entities by types of economic activity (2013-2018). Retrieved from http://www.ukrstat.gov.ua.

3. State Statistics Service of Ukraine (n.d.). Costs of production of products (goods, services) of enterprises by type of economic activity (20122018). Retrieved from http://www.ukrstat.gov.ua.

4. State Statistics Service of Ukraine (n.d.). Current assets of enterprises by type of economic activity. Retrieved from http://www. ukrstat.gov.ua

5. Singh, M., \& Dixit, G.K. (2018). Modeling Customers Credit Worthiness using Enhanced Ensemble Model. International Journal of Computer Sciences and Engineering, 6(7), 1466-1470. https://doi. org/10.26438/ijcse/v6i7.14661470.

6. Mills, K. G. (2018). Small Businesses and Their Banks: The Impact of the Great Recession. In: Fintech, Small Business \& the American Dream. Palgrave Macmillan, Cham, 27-41. https://doi.org/10.1007/9783-030-03620-1 3 .

7. Sukhanova, A.V., Puhalskaya, N.A., \& Chernyi, B.S. (2018). Modern methods for evaluating the credit capacity of a borrower of banking institutions. Ekonomika i suspilstvo, 18, 821-826. https://doi. org/10.32782/2524-0072/2018-18-114.

8. Yudina, S. V., \& Nagornyuk, A. O. (2020). Comparisons of household credit evaluation models. Intellect XXI, 1, 98-103. https://doi. org/10.32782/2415-8801/2020-1.17.

9. Syrchyn, O. L. (2018). Theoretical basis for assessing the creditworthiness of bank borrower. Socio-Economic Research Bulletin, 1(65), 153-160. https://doi.org/10.33987/vsed.1(65).2018.153-160.

10. Markovych, T. (2019). Theoretical and methodological approaches to transformation of the active methodology for assessing creditworthiness of potential borrowers of commercial banks. Visnyk Kharkivskoho natsionalnoho ahrarnoho universytetu im. V.V. Dokuchayeva. Seriya: Ekonomichni nauky, 1, 224-236. https://doi. org/10.31359/2312-3427-2019-1-224.

11. Tomchuk, E. F., \& Sydorenko, I. M. (2019). Methods of conducting an account of debt receivables in the enterprise management system. Finanse, accounting, banks, 1(24), 94-101. https://doi. org/10.31558/2307-2296.2019.1.10.

12. Shkileva, A. A. (2018). Assessing the creditworthiness of construction enterprises by different method. International Journal of Engineering \& Technology, 7(3), 1308-1310. https://doi.org/10.14419/ijet. v7i3.14229.

13. Panchenko, O. M., \& Peresypkina, A. V. (2018). Assessment of creditworthiness in the system of internal control of the enterprise. Efektyvna ekonomika, 11. https://doi.org/10.32702/2307-2105-2018.11.91.

14. Kylnytska, Ye.V. (2018) Implementation of differentiated credit policy at mining enterprises. Naukovyi Visnyk Natsionalnoho Hirnychoho Universytetu, (2), 169-177. http://doi.org/10.29202/nvn$\mathrm{gu} / 2018-2 / 17$.

\section{Методичний підхід щодо оцінки кредитоспроможності контрагентів на підприємствах видобувної промисловості}

\section{Є. В. Кильницька ${ }^{1}$, С. В. Глухова ${ }^{2}$, О. М. Кітченко ${ }^{2}$}

1 - Харківський національний університет будівництва та архітектури, м. Харків, Україна, e-mail: dubrochka@ukr.n 2 - Національний технічний університет «Харківський політехнічний інститут», м. Харків, Україна

Мета. Формування комплексного методичного підходу до оцінки кредитоспроможності контрагентів підприємств видобувної промисловості у складі консервативної кредитної політики.

Методика. Вирішення поставлених у статті завдань здійснено з використанням сучасних загальнонаукових і 
спеціальних методів: абстрактно-логічний - для здійснення теоретичних узагальнень, формування висновків і рекомендацій; метод аналізу ієрархій - для обгрунтування пріоритетності структурних параметрів оцінки кредитоспроможності контрагентів підприємств видобувної промисловості. Крім того, використані результати власних попередніх досліджень із проблематики управління дебіторською заборгованістю.

Результати. Запропонована пріоритетність структурних параметрів оцінки кредитоспроможності контрагентів підприємств видобувної промисловості в межах консервативної кредитної політики, що обгрунтована за допомогою методу аналізу ієрархій. Синтезуючи утворену ієрархічну модель і теоретичні надбання із проблематики управління дебіторською заборгованістю, розроблена структурно-логічна послідовність оцінки кредитоспроможності контрагентів підприємств видобувної промисловості.

Наукова новизна. Розроблено комплексний методичний підхід до оцінки кредитоспроможності контрагентів підприємств видобувної промисловості в межах консервативної кредитної політики, який, на відміну від існуючих, являє собою чіткий алгоритм етапів оцінки, що грунтується на ієрархічній моделі структурних параметрів оцінки кредитоспроможності. Перевагами авторської розробки є: гнучкість системи на етапі формування критеріальної бази та структурних складових показників; чітка формалізація результатів; детальна структуризація параметрів оцінювання; можливість формування чіткого однозначного висновку щодо кредитоспроможності контрагентів підприємств видобувної промисловості; відповідність методичного інструментарію системи оцінювання сучасним особливостям діяльності підприємств видобувної промисловості.

Практична значимість. Полягає у застосуванні підприємствами видобувної промисловості комплексного методичного підходу до оцінки кредитоспроможності їх контрагентів, що сприятиме ефективному плануванню, регулюванню, контролю, раціональній організації взаємовідносин у сфері зворотного руху грошових коштів.

Ключові слова: кредитоспроможність, оцінювання, кредитна політика, дебіторська заборгованість, видобувна промисловість

Recommended for publication by A.I. Yakovlev, Doctor of Economic Sciences. The manuscript was submitted 01.12.20. 